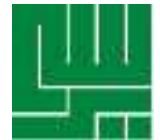

\title{
Perilaku Deteksi Dini Kanker Serviks Melalui Metode Pemeriksaan Inspeksi Visual Asam Asetat (IVA) pada Mahasiswa Magister FKM UI Menurut Teori Proceede- Preceede Tahun 2019
}

\author{
Behavior of Early Detection of Cervical Cancer Through \\ Visual Acetate Acid Inspection Method (IVA) in Master \\ Students of the Faculty of Public Health, University of \\ Indonesia According to Proceede-Preceede Theory in \\ 2019
}

\author{
Gabe Gusmi Aprilla1, Rachmadhi Purwana² \\ ${ }^{1}$ Mahasiswi Program Studi Magister Kesehatan Masyarakat, Fakultas \\ Kesehatan Masyarakat Universitas Indonesia, Depok, Indonesia \\ 2Departemen Kesehatan Lingkungan Fakultas Kesehatan Masyarakat \\ Universitas Indonesia, Depok, Jakarta
}
KATA KUNCI Kanker Serviks, Pemeriksaan Inspeksi Visual Asam Asetat, Proceede- Preceede
KEYWORDS Cervical Cancer, Acetic Acid Visual Inspection Examination, Proceede- Preceede

ABSTRAK Kanker serviks paling banyak ketiga di antara wanita di seluruh dunia. Menurut WHO tahun 2013, kematian akibat kanker serviks diproyesikan meningkat hampir $25 \%$ selama 10 tahun ke depan. Masalah yang sering terjadi pada negara miskin dan berpenghasilan menengah, kanker leher rahim ditemukan pada kondisi sudah parah. Dewasa ini dikenal beberapa metode skrining dan deteksi dini kanker leher rahim, namun yang sesuai dengan kondisi di negara berkembang termasuk di Indonesia adalah metode IVA karena mudah dilakukan, murah, cepat, sensitivitas tinggi dan akurat menemukan kelainan pada tahap kelainan sel (displasia) atau sebelum pra kanker.Studi pendahuluan yang dilakukan pada dua belas responden mahasiswi Pascasarjana FKM UI Angkatan 2018 yang sudah menikah, didapatkan hanya 3 orang yang pernah melakukan pemeriksaan IVA, sehingga peneliti tertarik untuk meneliti lebih jauh tentang perilaku deteksi dini kanker serviks melalui metode pemeriksaan inspeksi visual asam asetat (IVA) pada mahasiswa Magister FKM UI Tahun 2018.

Untuk mengetahui perilaku deteksi dini kanker serviks melalui pemeriksaan Inspeksi Visual Asam Asetat (IVA) pada Mahasiswa Magister FKM UI Tahun 2019.

Desain penelitian ini adalah penelitian kualitatif dilakukan di 
Fakultas Kesehatan Masyarakat Universitas Indonesia (FKM UI) pada bulan April 2019 terhadap 6 orang mahasiswi Magister FKM UI dengan teknik non probability sampling dalam hal ini adalah purposive sampling, suami mahasiswi dan bidan.

Perilaku pemeriksaan IVA mahasiswi Magister FKM UI Angkatan 2018 sudah bagus karena sudah banyak yang telah melakukan pemeriksaan IVA dan yang belum pemeriksaan IVA dikarenakan telah melakukan pemeriksaan papsmear meskipun ada juga yang masih malu dan takut melakukan pemeriksaan tersebut. Pengetahuan mahasiswi tentang pemeriksaan IVA sudah cukup bagus karena telah mampu menjelaskan dengan baik dan beragam mengenai kanker serviks, ciri-ciri, penyebab, deteksi dini, pemeriksaan IVA dan prosedurnya. Mahasiswi telah memiliki sikap positif terhadap pemeriksaan IVA meskipun masih ada yang merasa takut dan risih dengan pemeriksaan tersebut. Keterpaparan informasi mahasiswi tentang pemeriksaan IVA sudah cukup bagus khususnya yang bersumber dari media sosial. Dukungan tenaga kesehatan dalam pemeriksaan IVA menurut mahasiswi belum maksimal dilakukan. Fasilitas pemeriksaan IVA bagi mahasiswi mudah karena tersedia di fasilitas kesehatan terdekat di daerah masing-masing dengan biaya gratis bagi pengguna BPJS

Perilaku, pengetahuan dan keterpaparan informasi dalam pemeriksaan IVA pada mahasiswa sudah cukup bagus, sedangkan dukungan tenaga kesehatan dalam pemeriksaan IVA menurut mahasiswa belum maksimal.

ABSTRACT Cervical cancer is the third most prevalent among women worldwide. According to WHO in 2013, cervical cancer deaths are projected to increase by almost $25 \%$ over the next 10 years. A problem that often occurs in poor and middle-income countries, cervical cancer is found in an already severe condition. Nowadays, there are several methods of screening and early detection of cervical cancer, but those that are in accordance with conditions in developing countries, including in Indonesia, are IVA methods because they are easy to do, inexpensive, fast, high sensitivity and accurately find abnormalities at the stage of cell abnormalities (dysplasia) or before pre cancer. A preliminary study conducted on twelve respondents of FKM UI Postgraduate Batch 2018 students who were married, found only 3 people who had done an IVA examination, so researchers were interested in further researching the behavior of early detection of cervical cancer through visual inspection methods of acetic acid (IVA) ) to the 2018 FKM UI Masters students

To determine the behavior of early detection ofcervical cancer through the inspection of Acetic Acid Visual Inspection (IVA) in theMaster Program in the Faculty of Public Health, University 
of Indonesia in 2019.

The design of this study was a qualitative study conducted at the Faculty of Public Health, University of Indonesia in April 2019 with 6 students with non-probability sampling techniques in this case were purposive sampling, husband of students and midwives.

The behavior of IVA examination is good because there have been many who have done IVA examination and those who have not done IVA examination because they have done pap smear examination even though there are also some who are still shy and afraid to do the examination. Student knowledge about IVA examination is quite good because it has been able to explain well and varied about cervical cancer, its characteristics, causes, early detection, IVA examination and its procedures. Masters of the University of Indonesia Faculty of Public Health Masters Class of 2018 have a positive attitude towards IVA examination even though there are still some who feel scared and uncomfortable with the examination. The exposure of student information about IVA examination was quite good especially those from social media. The support of health workers in IVA examinations, according to students, is not maximally done. IVA examination facilities for female students are easy because they are available at the nearest health facility in their respective areas with free fees for BPJS users

Conclusion:Behavior, knowledge and information exposure in IVA examinations for students are quite good, while the support of health workers in IVA examinations according to students is not optimal.

Keywords:

\section{PENDAHULUAN}

Kanker leher rahim merupakan pekerjaan rumah yang berat bagi negara- negara di belahan dunia terutama negara berkembang. Penyakit ini merupakan kanker paling banyak ketiga di antara wanita di seluruh dunia. Menurut WHO tahun 2013, kematian akibat kanker serviks diproyesikan meningkat hampir 25\% selama 10 tahun ke depan. Sebuah penelitian menunjukkan bahwa lebih dari 270.000 kematian perempuan akibat kanker leher rahim terjadi setiap tahun di negara berkembang (Darwati, Muhith, \& Nurwijayanti, 2017). Adapun insidensi pada tahun 2008 bahwa lebih dari 30/100.000 per tahun di Afrika Timur dan Barat, 26,8/100.000 per tahun di Afrika Selatan, 24,6/100.000 per tahun di Asia SelatanTengah, 23,9/100.000 per tahun di Amerika Selatan, dan 23,0/100.000 per tahun di Afrika tengah (WilliamsBrennan, Gastaldo, Cole, \& Paszat, 2012).

\section{Correspondence:}

Gabe Gusmi Aprilla, Magister Kesehatan Masyarakat

Univeristas Indonesia, Depok, Indonesia Email: gabe.gusmi@mail.com 
orang meninggal setiap satu jamberdasarkan data Riset Kesehatan Dasar (Riskesdas) tahun 2013, prevalensi tumor/kanker adalah 1,4 per 1000 penduduk. Prevalensi tertinggi terdapat di DI Yogyakarta $(4,1 \%)$, di ikuti Jawa Tengah (2,1\%), Bali (2\%), Bengkulu, dan DKI Jakarta masing-masing 1,9 per mil dengan kanker tertinggi pada perempuan adalah kanker payudara (21\%) dan kanker leher rahim (10\%) (Kemenkes RI, 2015).Beban pembiayaan untuk penyakit kanker semakin meningkat pada negara-negara berkembang (Ferlay et al., 2015). Di Indonesia, dana yang digunakan untuk penanganan kanker cukup tinggi, pengobatan kanker pada Jamkesmas tahun 2012 menempati urutan kedua setelah hemodialisa yaitu sebanyak Rp.144,7 miliar. Pembiayaan ini makin meningkat tahun 2014 menjadi 905 milyar rupiah. Biaya penatalaksanaan kanker relatif mahal dari diagnosis hingga pengobatan. Untuk pengobatan pasien kanker harus menyediakan dana yang cukup besar untuk tindakan kemoterapi, radioterapi dan lainnya (Kemenkes RI, 2015).

Menurut Rasjadi, Hartati et al., (2010), kanker leher rahim merupakan sebuah tumor ganas yang tumbuh di dalam leher rahim yaitu bagian terendah dari rahim yang menempel pada puncak vagina. Penyebab terbesar kanker leher rahim adalah infeksi HPV (Human Pappiloma Virus) yang menular lewat hubungan seksual. Seorang perempuan bisa terinfeksi virus ini pada usia belasan tahun dan baru diketahui mengidap kanker 20-30 tahun kemudian setelah infeksi menyebar yang pada umumnya baru terdeteksi saat seseorang berusia paruh baya, sekitar 40 tahunan (Yuliwati, 2012).

Masalah yang sering terjadi pada negara miskin dan berpenghasilan menengah, kanker leher rahim ditemukan pada kondisi sudah parah dan di diagnosis pada stadium lanjut sehingga pengobatan kuratif tidak membuahkan hasil yang maksimal (Anwar et al., 2018). Kesadaran dan keputusan untuk melakukan deteksi dini dipengaruhi oleh Beberapa faktor penyebab antara lain meliputi luas wilayah demografi, pengetahuan, pendapatan keluarga, kesinambungan penyampaian informasi, dan kekurangan sumber daya manusia sebagai pelaku skrining sehingga harapan untuk menemukan penyakit kanker leher rahim stadium dini masih sulit (Ummiyati, Widati, \& Hargono, 2017). Menurut (Emilea, ova, 2010) masalah kanker leher rahim di Indonesia terkendala dengan kondisi sosial masyarakat dan sosial ekonomi, sosial masyarakat, termasuk didalamnya adalah berkaitan dengan konsep tabu dalam norma masyarakat yang mana pemeriksaan kanker leher rahim ini dilakukan pada bagian yang sensitif dan tertutup sehingga bukanlah hal mudah mendorong dan meminta perempuan untuk membuka dan mengijinkan pemeriksaan tersebut (Yuliwati, 2012; Nurjana \& Abu, 2016). Menurut (Rochmawati, Ika,2011), bahwa perilaku masih menjadi penghambat pada Wanita Usia Subur (WUS) untuk melakukan pemeriksaan dini kanker leher rahim. Sementara proses perubahan/pembentukan sikap dan perilaku seseorang bisa dipengaruhi oleh faktor dari dalam dan dari luar individu itu sendiri. Sikap seseorang dapat berubah dengan intervensi informasi dari kelompok 
sosialnya (Eka,Arsita,2010). Sikap seseorang terhadap perilaku deteksi dini kangker leher rahim ini bisa dilakukan dengan pendekatan terhadap cara mengintervensi sehingga terjadi perubahan perilaku dalam melakukan deteksi dini kangker leher rahim ini.

Berdasarkan teori Lawrence Green (1980) perilaku ditentukan oleh tiga faktor utama yaitu; faktor predisposisi adalah faktor yang mempermudah terjadinya perilaku seperti pengetahuan, sikap, tradisi dan kepercayaan, sistim nilai yang dianut,tingkat pendidikan dan tingkat sosial ekonomi; faktor pemungkin adalah ketersediaan sarana dan sarana pendukung kesehatan seperti tempat pelayanan, media dan alat dan sebagainya; dan faktor penguat adalah faktor yang memperkuat terjadinya perilaku seperti sikap dan perilaku tokoh masyarakat, tokoh agama, kader kesehatan, undang-undang dan peraturan lainnya (Notoatmodjo, Soekidjo, 2007). Dewasa ini telah dikenal beberapa metode skrining dan deteksi dini kanker leher rahim yaitu tes pap smear dan IVA, pembesaran IVA dengan gineskopi, kolposkopi, servikografi, thin Prep, dan tes HPV, namun yang sesuai dengan kondisi di negara berkembang termasuk di Indonesia adalah dengan metode IVA dengan pertimbangan mudah dilakukan, biaya relatif murah, cepat, tingkat sensitivitas tinggi dan cukup akurat untuk menemukan kelainan pada tahap kelainan sel (displasia) atau sebelum pra kanker (GP Mayun Mayura, 2012). Untuk itu dianjurkan tes IVA bagi semua perempuan berusia 30-50 tahun dan perempuan yang sudah melakukan hubungan seksual (Kemenkes RI, 2015).
Studi
pendahuluan yang
dilakukan pada dua belas (12)
responden mahasiswi Pascasarjana FKM UI Angkatan 2018 yang sudah menikah, didapatkan hanya 3 orang yang pernah melakukan pemeriksaan IVA, sehingga kelompok kami tertarik untuk meneliti lebih jauh tentang perilaku deteksi dini kanker serviks melalui metode pemeriksaan inspeksi visual asam asetat (IVA) pada mahasiswa Magister FKM UI Tahun 2019.

\section{Kanker Serviks}

Serviks uterus merupakan organ yang berbentuk kerucut dengan panjang 2-4 sentimeter dan diameter luar sekitar 2,5 sentimeter, dengan saluran di bagian tengah berbentuk kumparan (Benson, 2010; Longo, 2009; Monif, 2012). Kanker merupakan pertumbuhan sel baru yang tidak terkontrol dan memiliki sifat proliferasi lebih cepat dengan pertumbuhan yang progresif dan pola penyebaran yang tidak teratur serta dapat mempengaruhi jaringan di sekitarnya (Monif, 2009; Stead, 2007; WHO, 2011). Kanker yang mengenai serviks akan menyebabkan serviks akan menunjukkan perubahan gambaran pada visual (Rasjidi, 2010). Etiologi dari kanker serviks adalah Human Papilloma Virus (HPV) (Andriyono, 2009; Yatim, 2011). Infeksi dari HPV secara signifikan berkaitan dengan kanker serviks intraepitel dan kanker serviks yang sudah infasi. Banyak tipe virus HPV yang sering dianggap berkaitan, menurut Andrijono (2009) tipe HPV diklasifikasikan dalam tiga golongan yaitu resiko tinggi, kemungkinan resiko tinggi, dan resiko rendah. Faktor resiko terjadinya kanker serviks meliputi melakukan hubungan seksual pada 
usia dini, berganti-ganti pasangan seksual, multiparitas, kontrasepsi hormonal dan merokok (Andrijono, 2009; Norwitz Errol R, 2007; Rasjidi, 2010). Selain faktor pemicu tersebut, perempuan yang mempunyai partner yang pernah melakukan hubungan seksual dengan perempuan yang menderita kanker serviks mempunyai resiko tinggi untuk terkena kanker serviks juga (Yatim, 2005; Longo, 2009).Menurut Wall (2010), dalam penelitiannya yang bertujuan untuk memodifikasi faktor penghambat wanita dalam melakukan deteksi dini kanker serviks. Didapatkan data bahwa penyebab kanker serviks terbesar adalah karena penyakit menular seksual dan prevalensi tertinggi terjadi pada wanita usia produktif. Faktor risiko paling besar terjadi pada wanita yang mempunyai multi partner, melakukan hubungan seksual pada usia muda, aktifitas seksual dimulai pada usia kurang dari 19 tahun dan wanita dengan paritas tinggi. Gejala kanker serviks tahap awal adalah adanya perdarahan pervaginam, misalnya setelah melakukan hubungan seksual atau perdarahan menstruasi lebih banyak atau timbul perdarahan diantara siklus menstruasi (Norwitz, 2007).

Sementara gejala lebih lanjut dirasakannya nyeri pada daerah pinggang, kaki, kelelahan, menorhagia dan perdarahan spontan juga dapat terjadi. Keluhan dan gejala akibat bendungan kanker yang dirasakan meliputi gangguan berkemih, udem kaki akibat penekanan pada pembuluh darah balik dan penekanan pada syaraf menyebabkan penderita merasakan nyeri pada pinggang bagian bawah (Sherwood, 2005; Yatim, 2011). Tujuan dari diagnosis adalah untuk dapat mendetaksi kanker pada stadium yang masih dini, dengan demikian kanker dapat di diagnosis sebelum metastase terjadi untuk mempermudah penanganannya (Andrijono, 2009; Wall, 2010).

Dengan memakai metode biofisika, seperti sinar $\mathrm{x}$, TomografiComputer (CT), Ultrasonografi maupun Magnetic Resonance Imaging (MRI) biasanya tumor terdeteksi setelah mencapai jumlah sel sebanyak 10-9 atau dengan diameter 2 sentimeter. Sebaliknya dengan metode imunokimiawi (petanda tumor) generasi ketiga, tumor dengan jumlah sel sekitar satu juga dapat terdeteksi (Rasjidi, 2010). Pencegahan primmer kanker serviks dapat dilakukan dengan edukasi pola hidup sehat, meliputi menunda onset aktifitas seksual, penggunaan kontrasepsi barier dan penggunaan vaksin HPV (Jasiak, 2008; Rasjidi, 2010). Pencegahan sekunder dibagi menjadi dua kriteria, pencegahan sekunder pada pasien dengan resiko sedang, jika hasil tes pap tiga kali berturut-turut negatif dianjurkan pemeriksaan tes pap tiap tahun. Pencegahan sekunder pada pasien dengan resiko tinggi (wanita yang melakukan hubungan seksual saat usia kurang dari 18 tahun dan wanita yang mempunyai banyak partner seharusnya melakukan tes pap tiap tahun, dimulai dari pertama seksual aktif. Interval sekarang ini dapat diturunkan menjadi 6 bulan untuk pasien dengan resiko khusus seperti wanita dengan riwayat penyakit seksual berulang (Rasjidi, 2008; Wall, 2010).

Sementara pencegahan tersier dilakukan dengan mendapatkan pelayanan di rumah sakit (diagnosa dan pengobatan) serta perawatan 
paliatif sesuai dengan kondisi kanker (Andrijono, 2009). Beberapa metode skrining yang dikenal adalah tes pap, kolposkopi, servikografi, pap net, tes molekular DNA HPV, IVA dan IVA dengan pembesaran gineskopi (Nuranna, 2001). Tetapi yang umum digunakan untuk skrining adalah tes pap. Di negara maju yang telah melaksanakan skrining dengan tes pap secara mapan dan telah berlangsung beberapa dekade, terbukti mampu menurunkan angka kematian akibat kanker serviks $50-60 \%$ dalam kurun waktu 20 tahun (WHO, 1986). Di negara berkembang, program skrining dengan pap smear sangat sulit dilakukan karena kurang praktis, membutuhkan pemeriksaan laboratorium kompleks sehingga butuh ahli patologi, hasilnya pun cukup lama 1-2 minggu dan bagi masyarakat yang tinggal di pelosok sulit untuk dijangkau. Keterbatasan fasilitas dan sumber daya manusia terlatih merupakan faktor kendala yang dihadapi dalam pelaksanaan program skrining dengan tes pap (WHO, 1986).

Oleh karena itu di negara berkembang, perlu ada metode pemeriksaan lain sebagai pengganti tes pap. WHO (2002) merekomendasikan bahwa skrining dengan sitologi (tes pap) tetap merupakan teknik skrining standar untuk negara maju, namun untuk tes Inspeksi Visual dengan Asam Asetat (IVA) dapat menggantikan sitologisebagai teknik skrining di negara-negara dengan sumber daya terbatas.Terutama untuk masyarakat yang jauh dari fasilitas kesehatan adalah tes IVA, sedangkan untuk masyarakat kotanya, tersedia metode deteksi dini dengan cara Pap Smear (Depkes, 2012). Metode IVA adalah pemeriksaan serviks secara visual menggunakan asam cuka (IVA) berarti melihat serviks dengan mata telanjang untuk mendeteksi abnormalitas setelah pengolesan asam asetat atau cuka (3$5 \%)$. Daerah yang tidak normal akan berubah warna dengan batas yang tegas menjadi putih (acetowhite), yang mengindikasikan bahwa serviks mungkin memiliki lesi prakanker (Depkes, 2012). Pemeriksaan IVA pertamakali diperkenalkan oleh Hinselman (1925) dengan cara mengusap serviks dengan kapas yang telah dicelupkan ke dalam asam asetat $3 \%$. Adanya tampilanbercak putih setelah pulasan asam asetat kemungkinan diakibatkan lesi prakanker serviks. Cara ini kemudian dikembangkan oleh WHO sejak tahun 1990 di India, Thailand dan Zimbabwe (Moerdijat, et.al, 2010).

Keunggulan Tes IVA (WHO, 2002; ACCP, 2004): Akurasi tes IVA pada beberapa penelitian terbukti cukup baik, Sensitivitas setara dengan tes pap untuk mendetaksi lesi derajat tinggi, Pelatihan IVA untuk tenaga medis lebih cepat dan sederhana dibandingkan sitoteknisi. Hasil pemeriksaan dapat segera diketahuiMurah dan sederhana. Dapat dikerjakan pada fasilitas kesehatan dengan sumber daya terbatas, dapat dikerjakan kapan saja, tidak perlu persiapan klien

\section{Teori Proceede-Preceede}

Model Precede-Proceed dikembangkan oleh Green dan Kreuterpada tahun 1980. Model ini paling cocok diterapkan dalam perencanaan dan evaluasi promosi kesehatan, yang dikenal dengan model Precede (Predisposing, Reinforcing and Enabling Causes inEducational Diagnosis and Evaluation). 
Precede merupakan kerangka untuk membantu perencanaan mengenal masalah, mulai dari kebutuhan pendidikan sampai pengembangan program. Pada tahun 1991, model ini disempurnakan menjadi model Precede-Proceede. Proceede merupakan singkatan dari Policy, Regulatory, and Organizational Contructsin Educational and environmental Development. Green menganalisis perilaku manusia dimulai dari tingkat kesehatan, bahwa kesehatan seseorang atau masyarakat dipengaruhi oleh 2 faktor pokok, yaitu faktor perilaku (behavior causes) dan faktor luar perilaku (non behavior causes).

Meskipun model ini mendasarkan diri pada Model Kepercayaan Kesehatan atau Health Belief Model dan sistem konseptual lain namun model Precede merupakan model sejati, yang lebih mengarah kepada upaya pragmatik mengubah perilaku kesehatan daripada sekedar upaya pengembangan teori. Green dan rekannya menganalisis kebutuhan kesehatan komunitas dengan cara menetapkan lima diagnosis berbeda, yaitu diagnosis sosial, diagnosis epidemiologi, diagnosis perilaku, diagnosis pendidikan, dan diagnosis administrasi/kebijakan.

Dalam aplikasinya, PrecedeProceed dilakukan bersama dalam proses perencanaan, pelaksanaan, dan evaluasi. Precede digunakan pada fase diagnosis masalah,penetapan prioritas dan tujuan program, sedangkan Proceed digunakan untuk menetapkan sasaran dan kriteria kebijakan, pelaksanaan, dan evaluasi. Menurut Schmidt dkk, model ini paling banyak diterima dan telah berhasil diterapkan di perencanaan program.
Komprehensif dalam banyak susunan yang berlainan, serta model ini dianggap lebih berorientasi praktis. Berdasarkan pemikiran tersebut, Lawrence Green mengusulkan perencanaan promosi kesehatan melalui Precede framework dan Proceed framework sebagai terapi terhadap perilaku lama. Jika Precede merupakan diagnosis, Proceed adalah terapi dalam promosi kesehatan.

Pengertian Model PrecedeProceed Green (1980) telah mengembangkan suatu model pendekatan yang dapat digunakan untuk membuat perencanaan dan evaluasi kesehatan yang dikenal demgam Precede. Precede adalah merupakan singkatan dari Predisposing, Reinforcing, Enabling,

Causes, Educational Diagnosisand Evaluation.

Precede memberikan serial langkah yang menolong perencana untuk mengenal masalah mulai dari kebutuhan pendidikan sampai pengembangan program untuk memenuhi kebutuhan tersebut. Namun demikian pada tahun 1991 Green menyempurnakan kerangka tersebut menjadi Precede-Proceed. Proceed (Policy, Regulatory, Organizational Construct in Educational and Environmental Development). PrecedeProceed harus dilakukan secara bersama. Tujuan Model Model PrecedeProceed menjadi bagian paling penting dari perencanaan program adalah analisis komunitas atau yang biasa dikenal sebagai analisis kebutuhan. Keberhasilan program promosi kesehatan tergantung dari data yang didapat tentang individu, kelompok atau sistem yang akan menjadi fokus dari program. Model ProcedeProceed juga berperan penting dalam perencanaan pendidikan dan promosi 
kesehatan karena menyediakan bentuk untuk mengidentifikasi faktor-faktor yang berkaitan dengan masalah kesehatan, perilaku dan pelaksanaan program. Model Precede adalah kerangka untuk proses perkembangan sistematis dan program-program edukasi kesehatan, dikembangkan antara tahun 1968-1974. Tujuan Precede pada fase diagnosis masalah, menetapkan prioritas masalah dan diagnosis program. Preced untuk diagnosa dan perencanaan memimpin edukator kesehatan untuk berpikir secara deduktif, untuk memulai dengan konsekuensi final dan bekerja kembali ke penyebab asli. Proceed ditambahkan pada model ini pada akhir 1980 berdasarkan pada percobaan Lawrence W. Green bersama dengan Marshall Krueter pada berbagai macam posisi dengan pemerintahan federal dan Kaiser Family Foundation. Tujuan Proceed digunakan untuk menetapkan untuk menetapkan sasaran dan criteria kebijakan, serta implementasi dan evaluasi. Kerangka Precede didirikan pada persyaratan dari empat disiplin: Epidemiologi, Ilmu pengetahuan sosial dan tindakan, Administrasi, Edukasi. Dalam penerapan Precede, dua proporsi dasar ditekan: Pertama, kesehatan dan tindakan kesehatan disebabkan oleh faktor-faktor ganda, dan kedua, karena kesehatan dan tindakan kesehatan ditentukan oleh faktor-faktor ganda, upaya-upaya edukasi kesehatan untuk mempengaruhi tindakan harus multidimensional.

\section{Surveillance, Planing aad Eraluating for Policy and Action: PRECEDE-PR.OCFES NODEL'}

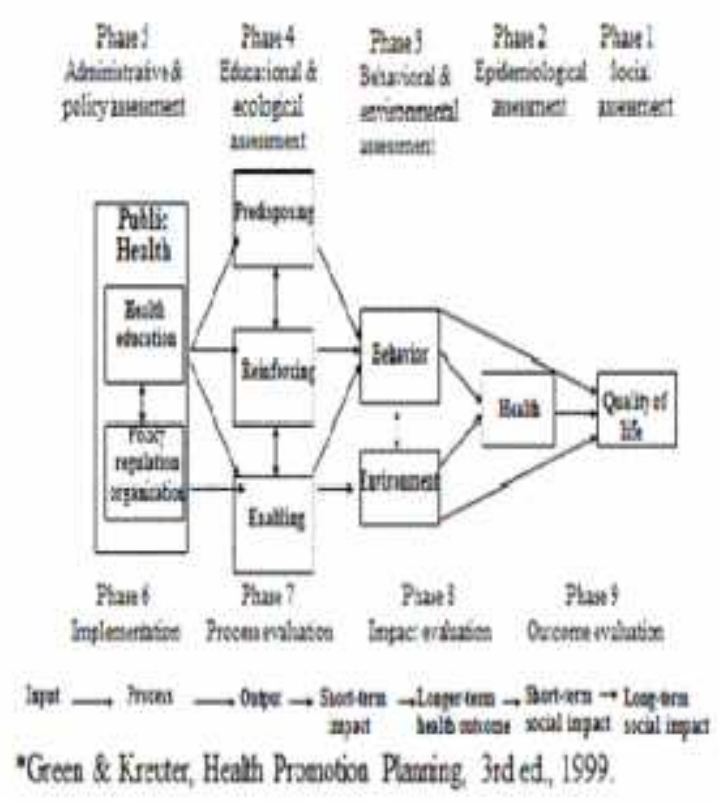

Gambar1. Precede - Proceed Model

\section{Perilaku Pemeriksaan IVAFaktor predisposisi(predisposing factors)}

Faktor yang mempermudah atau mendasari untuk terjadinya perilaku tertentu. Merupakan anteseden dari perilaku yang menggambarkan rasional atau motivasi melakukan suatu tindakan, nilai dan kebutuhan yang dirasakan, berhubungan dengan motivasi individu atau kelompok untuk bertindak. Menurut penelitian yang dilakukan oleh Kurniawati, Indah (2015) dalam Masters Thesis Universitas Sebelas Maret tentang Pengaruh Pengetahuan, Motivasi Dan Dukungan Suami Terhadap Perilaku Pemeriksaan IVA Pada Kelompok Wanita Usia Subur Di Puskesmas Kedungrejo, faktor pengetahuan dan motivasi yang kurang dapat mempengaruhi perilaku pemeriksaan IVA pada wanita usia subur. 
Dalam tesisnya juga disebutkan penelitian terkait oleh Maharsie dan Indarwati (2012) terhadap perempuan 30-50 tahun di kelurahan Jebres terhadap 66 responden menunjukkan bahwa ada hubungan yang signifikan antara pengetahuan tentang kanker serviks dengan keikutsertaan ibu melakukan tes IVA. Berdasarkan hasil penelitian ini dapat dikatakan bahwa keputusan untuk melakukan deteksi dini kanker leher rahim tidak hanya berasal dari faktor pengetahuan, namun terdapat confounding factorsyang dapat merancukan pengetahuan yang telah baik mengenai deteksi dini, menjadi eksekusi perilaku yang tidak tepat yaitu menolak melakukan deteksi dini berupa IVA atau Papsmear. Sehingga petugas kesehatan perlu lebih giat menjalankan tugas konselor bagi PUS guna menimbulkan kepercayaan tentang pentingnya deteksi dini ini. Sebab banyak PUS yang tahu (tingkat pengetahuan pertama dari individu) tetapi tidak mau; atau PUS yang tidak tahu dan tidak mau melakukan deteksi dini kanker leher rahim.

Konseling yang dilakukan dengan pendekatan secara mendalam dan memberikan penyuluhan kepada para perempuan tentang pentingnya deteksi dini kanker leher rahim bagi kesehatan reproduksi dan bagi kelangsungan hidupnya. Menurut penelitian yang dilakukan oleh Christin Angelina Febriani dari Fakultas Kesehatan Masyarakat, Universitas Malahayati Bandar Lampung tentang faktor-faktor yang berhubungan dengan deteksi dini kanker leher rahim di Kecamatan Gisting Kabupaten Tanggamus Lampung bahwa hubungan sikap dapat mempengaruhi pemeriksaan IVA dalam rangka deteksi dini kanker leher rahim. Hal ini sesuai menurut Notoatmodjo (2014), bahwa sikap merupakan reaksi atau respon seseorang yang masih tertutup terhadap suatu stimulasi atau obyek tertentu, yang sudah melibatkan faktor pendapat dan emosi yang bersangkutan (senang tidak senang, setuju-tidak setuju, baik-tidak baik, dan sebagainya). Hasil penelitian yang dilakukan oleh Christin Angelina Febriani juga sejalan dengan penelitian Adi (2011) bahwa sikap wanita dewasa di wilayah Kabupaten Banyumas memiliki hubungan yang signifikan dengan pemeriksaan deteksi dini kanker serviks. Sejalan pula dengan penelitian Martini yang mengatakan bahwa sikap berhubungan kuat dengan tindakan pemeriksaan pap smear di puskesmas Sukawati II tahun 2013. Peneliti berasumsi bahwa sikap positif dari individu tidak serta merta berujung pada perilaku kesehatan yang baik pula, dalam hal ini adalah melakukan IVA atau papsmear. Berbagai faktor perancu akan menghampiri dan dapat merubah sikap positif tadi menjadi perilaku yang tidak positif. Faktor perancu tersebut terkait dengan faktor status sosial ekonomi dan takut jika di ketahui penyakitnya. Sehingga walaupun responden bersikap positif namun tetap enggan melakukan deteksi dini kanker leher rahim. Namun, sebagian besar individu yang berangkat dari pengetahuan, persepsi dan sikap yang positif terhadap suatu topik masalah kesehatan. Maka, kans untuk terjadi eksekusi perilaku kesehatan yang positifpun akan lebih besar. Pendidikan juga dapat mempengaruhi pemeriksaan IVA untuk mendeteksi dini kanker leher rahim. Pendidikan adalah proses di mana semua kemampuan manusia (bakat dan kemampuan yang 
diperoleh) yang dapat dipengaruhi oleh pembiasaan, disempurnakan dengan kebiasaan-kebiasaan yang baik melalui sarana yang secara artistik dibuat dan dipakai oleh siapapun untuk membantu orang lain atau dirinya sendiri mencapai tujuan yang ditetapkan yaitu kebiasaan yang baik (Adler, 2011).

Pendidikan berkaitan erat dengan segala sesuatu yang bertalian dengan perkembangan manusia mulai perkembangan fisik, kesehatan, keterampilan, pikiran, perasaan, kemauan, sosial sampai kepada perkembangan iman. Berdasarkan penelitian ini, peneliti berpendapat bahwa pada responden dengan tingkat pendidikan tinggi yang melakukan deteksi dini kanker leher rahim karena perempuan yang berpendidikan tinggi cenderung lebih memperhatikan diri dan keluarganya. Pendidikan dapat mempengaruhi sesorang dalam mengambil keputusan dalam deteksi dini kanker leher rahim semakin tinggi pendidikan semakin baik pengetahuan dan akan semakin bijaksana dalam mengambil keputusan dalam deteksi dini kanker leher rahim. sedangkan perempuan dengan pendidikan rendah yang melakukan deteksi dini kanker leher rahim Febriani, faktor-faktor yang Berhubungan dengan Deteksi Dini Kanker Leher Rahim 233 menurut pendapat peneliti pendidikan akan mempengaruhi pengtahuan seseorang dan pendidikan dan pengetahuan tidak hanya bias di dapat dari pendidikan secara formal melainkan ada yang didapat secara informal salah satunya pendidikan yang didapat responden berasal dari kegiatan yang sering dilakukan secara rutin seperti pada kegiatan posyandu, pengajian, pertemuan PKK yang secara tidak langsung dapat meningkatkan pengetahuan perempuan. Sedangkan pada hasil penelitian sebanyak 163 responden berpendidikan rendah tidak melakukan deteksi dinikanker leher rahim karena dapat disebabkan karena pada pendidikan rendah dimana pengetahuan dan cara pandang seseorang lebih sempit dan tidak mudah untuk menerima ide atau saran yang baru sehingga responden lebih memilih untuk tidak melakukan deteksi dini kanker leher rahim. Tingkat pendidikan merupakan salah satu faktor yang sangat menentukan pengetahuan dan persepsi seseorang terhadap pentingnya suatu hal termasuk pentingnya deteksi dini kanker leher rahim, disebabkan seseorang yang berpendidikan tinggi akan lebih luas pandangannya dan lebih mudah menerima ide dan tata cara kehidupan baru. Sehingga dapat disimpulkan bahwa orang yang berpendidikan tinggi akan melakukan deteksi dini kanker leher rahim

\section{Faktor pemungkin (enabling factors)}

Faktor yang memungkinkan untuk terjadinya perilaku tertentu atau memungkinkan suatu motivasi direalisasikan. Yang termasuk dalam kelompok faktor pemungkin adalah ketersediaan pelayanan kesehatan, aksesibilitas dan kemudahan pencapaian pelayanan kesehatan baik dari segi jarak maupun segi biaya dan sosial serta adanya peraturan dan komitmen masyarakat dalam menunjang perilaku tersebut. Menurut penelitian Christin Angelina Febriani Fakultas Kesehatan Masyarakat, Universitas Malahayati Bandar Lampung tentang faktor-faktor yang berhubungan dengan deteksi dini kanker leher rahim di Kecamatan Gisting Kabupaten Tanggamus 
Lampung, peran kader kesehatan memiliki hubungan dengan pemeriksaan IVA untuk deteksi dini kanker leher rahim. Seorang kader kesehatan harus bisa memberi contoh, member informasi dan penyuluhan kesehatan kepada masyarakat dilingkungan tempat tinggalnya melalui pertemuan-pertemuan di desanya, baik itu informasi kesehatan dari puskesamas maupun dari dinas kesehatan langsung. Peran aktif kader dapat mempengaruhi mau atau tidaknya seorang perempuan untuk meakukan deteksi dini kanker leher rahim. Kader kesehatan mempunyai tugas yang mulia, kader diharapkan dapat berperan sebagai pemberi informaasi kesehatan kepada masyarakat, penggerak masyarakat untuk melaksanakan pesan-pesan kesehatan seperti mendatangi posyandu dan melaksanakan hidup bersih dan sehat, dan sebagainya. Selain dari pada itu kader juga dapat berperan sebagai orang yang pertama kali menemukan jika ada masalah kesehatan di daaerahnya dan segera melaporkan kesehatan setempat. Kader merupakan penghubung antara masyarakat dengan tenaga kesehatan karena kader selalu berada di tengahtengah masyarakat.

$$
\text { Hubungan Informasi yang }
$$
didapat memiliki hubungan dengan deteksi dini kanker leher rahim. Informasi yang diperoleh tentang kanker leher rahim dapat diperoleh melalui penyuluhan oleh tenaga kesehatan melalui pertemuan di pengajian, pertemuan di tingkat desa, informasi dari teman atau tetangga maupun keluarga yang pernah melakukan pemeriksaan deteksidini kanker leher rahim selain itu informasi juga dapat diperoleh melalui poster- poster yang disediakan oleh pemerintah daerah. Selain itu pila dapat diperoleh melalui sarana komunikasi. Sebagai sarana komunikasi, berbagai bentuk media masa seperti televisi, radio, surat khabar, majalah, dll, mempunyai pengaruh besar dalam pembentukan opini dan kepercayaan orang. Dalam penyampaian informasi sebagai tugas pokoknya, media masa membawa pula pesan-pesan yang berisi sugesti yang dapat mengarahkan opini seseorang. Adanya informasi baru mengenai sesuatu hal memberikan landasan kognitif baru bagi terbentuknya sikap terhadap hal tersebut apabila cukup kuat akan memberi dasar afekif dalam menilai sesuatu hal sehingga terbentuklah arah sikap tertentu. Peneliti berasumsi bahwa sebagai sarana komunikasi, berbagai media massa seperti televisi, radio, mempunyai pengaruh besar dalam pembentukan opini dan kepercayaan orang. Adanya informasi baru mengenai sesuatu hal memberikan landasan kognitif baru bagi terbentuknya sikap terhadap hal tersebut. Pesan-pesan sugestif yang dibawa informasi tersebut.

\section{Faktor penguat (reinforcing factors)}

Faktor yang memperkuat (atau kadang-kadang justru dapat memperlunak) untuk terjadinya perilaku tersebut. Merupakan faktor yang memperkuat suatu perilaku dengan memberikan penghargaan secara terus menerus pada perilaku dan berperan pada terjadinyapengulangan. Merupakan faktor yang berperan setelah suatu perilaku telah dimulai. Faktor ini mendukung pengulangan atau tetapnya suatu perilaku dengan memberikan suatu penghargaan atau insentif secara berkelanjutan serta 
hukumansebagai konsekuensi dari suatu perilaku. Hal tersebut digunakan untuk memotivasi dan menguatkan perilaku sehat dan outcome. Reinforcement bisa datang dari individu atau kelompok, seseorang atau institusi dalam lingkungan fisik atau sosial seperti keluarga, guru, akademis, dan lain-lain. Hal penting untuk memahami reinforcing factor adalah sejauh mana ketidakadannya akan berarti kehilangan dukungan untuk tindakan dari individu atau kelompok. Elemen penting pada fase ini adalah pemilihan faktor yang dapat dimodifikasi, yang paling dapat menghasilkan perubahan perilaku Proses pemilihan mencakup mengidentifikasi, memilah faktorfaktor ini ke dalam kategori-kategori (positif dan negatif), menempatkan prioritas pada tiap kategori, dan memprioritaskan salah satu kategori. Prioritas faktor bergantung kepada tingkat kepentingandan kemampuan untuk diubah. Learning objectives dari faktor-faktor terpilih ini kemudian dikembangkan. Pemilihan faktor-faktor mana yang harus diubah untuk memulai dan menjaga (maintain) perubahan perilaku dilakukan pada fase ini karena intervensi spesifik juga disusun pada fase ini. Diagnosis edukasi dan organisasi ini lah yang digunakan untuk melihat hal-hal spesifik yang dapat meningkatkan atau menurunkan perilaku-perilaku yang berhubungan dengan kesehatan.

Menurut penelitian yang dilakukan oleh Kurniawati, Indah dalam Masters thesis, Universitas Sebelas Maret tahun 2015 tentang pengaruh pengetahuan, motivasi dan dukungan suami terhadap perilaku pemeriksaan IVA pada kelompok wanita usia subur di Puskesmas Kedungrejo, dukungan suami yang kurang mempengaruhi perilaku pemeriksaan IVA pada wanita usia subur. Dalam tesisnya, House dan Kahn dalam Friedman (2010) menyebutkan dukungan keluarga adalah sebuah proses yang terjadi sepanjang masa kehidupan, sifat dan jenis dukungan berbeda dalam berbagai tahap-tahap siklus kehidupan. Dukungan keluarga dapat berupa dukungan sosial internal, seperti dukungan dari suami, istri atau dukungan dari saudara kandung dan dapat juga berupa dukungan keluarga eksternal bagi keluarga inti. Dukungan keluarga membuat keluarga mampu berfungsi dengan berbagai kepandaian dana akal.

Sebagai akibatnya, hal ini meningkatkan kesehatan dan adaptasi keluarga. Penelitian ini tidak sejalan dengan penelitian yang dilakukan Linadi (2013), menunjukkan bahwa dukungan suami memiliki hubungan yang signifikan dengan ke ikut sertaan PUS dalam deteksi dini kanker leher rahim di perumahan Pucung Gading Semarang. Juga penelitian yang dilakukan Gustiana, Dewi, Nurchayati (2015) dukungan suami mempunyai hubungan dengan perilaku pencegahan kanker serviks pada wanita usia subur. Berdasarkan hasil penelitian dimana pada responden yang didukung suami tetapi masih tetap tidak melakukan deteksi dini kanker leher rahim, hal ini bisa dikarenakan walaupun mendapat dukungan suami, namun ketika responden tidak mau dan merasa tidak siap melakukan deteksi dini, pada akhirnya akan mempengaruhi keputusan responden dalam melakukan deteksi dini kanker leher rahim. 


\section{Metodologi Penelitian}

Desain penelitian ini adalah penelitian kualitatif yaitu suatu jenis penelitian yang bertujuan untuk mendapatkan pemahaman yang bersifat umum terhadap kenyataan sosial dari perspektif partisipan dengan rancangan RAP (Rapid Assesment Prosedur) untuk memperoleh pemahaman tentang situasi dari perspektif informan secara cepat (Martha, 2016).Penelitian ini dilakukan di Fakultas Kesehatan Masyarakat Universitas Indonesia (FKM UI) pada bulan April 2019. Populasi penelitian ini yaitu mahasiswi Magister FKM UI Angkatan 2018 dan sampel penelitiannya yaitu 6 orang mahasiswi Magister FKM UI yang diambil dengan teknik non probability sampling dalam hal ini adalah purposive sampling yaitu bahwa sampel dipilih karena dianggap mampu menjawab tujuan penelitian yang dilakukan (Martha, 2016).

Adapun 6 orang mahasiswi sebagai sampel yang dimaksud adalah 3 orang mahasiswi yang belum pernah melakukan pemeriksaan IVA dan 3 orang mahasiswi yang telah melakukan pemeriksaan IVA beserta suaminya masing-masing. Kriteria inklusinya yaitu mahasiswi sudah menikah usia diatas 30 tahun. Adapun 6 orang mahasiswi ini sebagai informan telah dianggap sesuai dan cukup (appropriate dan adequacy) memberikan informasi mengenai perilaku pemeriksaan IVA pada mahasiswi Magister FKM UI Angkatan 2019. Selain mahasiswi dan suaminya, tenaga kesehatan juga menjadi informan kami (key infroman) untuk menjadi pembanding informasi yang diterima (validitas informan).

\section{HASIL}

Karakteristik Informandalam penelitian ini dibagi kedalam dua kriteria yaitu informan dan informan kunci. Informan adalah mahasiswi yang sudah melakukan pemeriksaan IVA, mahasiswi yang belum melakukan pemeriksaan IVA. Informan mahasiswi yang sudah dan belum pemeriksaan IVA, masing-masing 3 informan, dengan latar belakang pendidikan Sarjana. Informan mahasiswi yang sudah IVA, 1 orang memiliki 1 orang anak, 1 orang memiliki 2 orang anak, dan 1 informan sudah memiliki 3 orang anak. Informan mahasiswi yang belum IVA semuanya juga memiliki latar belakang pendidikan S1. Informan mahasiswi yang belum IVA, 1 orang memiliki 2 orang anak, dan 2 informan sudah memiliki 3 orang anak. Informan lain dalam penelitian ini terdiri dari suami mahasiswi yang sudah pemeriksaan IVA, suami mahasiswi yang belum pemeriksaan IVA. Suami dari mahasiswi yang sudah IVA memiliki latar belakang pendidikan sarjana. Suami dari mahasiswi yang belum IVA, 2 orang berpendidikan sarjana, dan 1 orang berpendidikan S2. Informan kunci penelitian ini adalah 2 orang bidan yang melakukan pemeriksaan IVA. Satu orang bidan pada klinik swasta, dan 1 orang bidan puskesmas. Dua orang bidan tersebut berpendidikan Diploma 3.

\section{Analisis Variabel Penelitian}

Pada analisis tematik akan menelaskan 7 variabel yang telah teridentifikasi yaitu: 1) Perilaku IVA, 2) pengetahuan tentang kanker serviks dan IVA, 3) sikap IVA, 4) sarana skrining IVA, 5) paparan informasi IVA, 6) dukungan tenaga kesehatan, 
dan 7) dukungan suami. Agar pemaparan hasil lebih mudah dipahami, coding dilakukan untuk menyederhanakan nama masingmasing informan yakni R1, R2 dan R3 untuk masing-masing mahasiswi yang sudah melakukan pemeriksaan IVA; R4, R5 dan R6 untuk masing-masing mahasiswi yang belum melakukan pemeriksaan IVA; R7,R8 dan R9 untuk suami masing-masing mahasiswi yang sudah melakukan pemeriksaan IVA; R10, R11 dan R12 untuk suami masingmasing mahasiswi yang belum melakukan pemeriksaan IVA serta R13 dan R14 untuk bidan klinik dan bidan puskesmas.

\section{Variabel Perilaku}

Ada hasil wawancara mendalam yang dilakukan didapatkan bahwa alasan mahasiswi melakukan pemeriksaan IVA adalah untuk deteksi dini kanker serviks. Alasan ini sama dengan alasan sebagian besar suami mereka, sedangkan sebagian kecil tidak tahu. Adapun mahasiswi yang belum pemeriksaan IVA, sebagaian besar karena sudah papsmear, sedangkan lainnya sebagian kecil karena takut dan suami mereka tidak tahu alasan istri mereka tidak melakukan pemeriksaan IVA. Adapun tujuan melakukan IVA bagi mahasiswi yang sudah IVA sama seperti alasan mereka melakukan IVA yaitu untuk deteksi dini kanker serviks. Tempat mahasiswi melakukan pemeriksaan IVA, sebagian besar (R2, R3) mengatakan di klinik dekat rumah dan lainnya (R1) mengatakan di rumah sakit. Mahasiswi yang telah melakukan 2 kali pemeriksaan IVA (R2, R3) kembali melakukannya di klinik kantor. Hasil dari pemeriksaan semua informan yang sudah IVA tersebut adalah normal. Selanjutnya, mahasiswi yang telah pemeriksaan IVA menambahkan bahwa agar terhindar dari kanker serviks, maka wanita harus menjaga kebersihan organ vital dan menjalankan gaya hidup sehat seperti tidak merokok, minum alcohol dan makan makanan yang sehat.

\section{Variabel Perilaku Mahasiswi dalam Pemeriksaan IVA}

Untuk mengetahui perilaku mahasiswi dalam pemeriksaan IVA, peneliti melakukan wawancara mendalam terhadap informan yang sudah dan belum melakukan pemeriksaan IVA dan suaminya masing-masing. Hasil wawancara mendalam yang dilakukan didapatkan bahwa alasan mahasiswi melakukan pemeriksaan IVA adalah untuk deteksi dini kanker serviks. Alasan ini sama dengan alasan sebagian besar suami mereka, sedangkan sebagian kecil tidak tahu. Adapun mahasiswi yang belum pemeriksaan IVA, sebagaian besar karena sudah papsmear, sedangkan lainnya sebagian kecil karena takut dan suami mereka tidak tahu alasan istri mereka tidak melakukan pemeriksaan IVA.Adapun tujuan melakukan IVA bagi mahasiswi yang sudah IVA sama seperti alasan mereka melakukan IVA yaitu untuk deteksi dini kanker serviks.

Tempat mahasiswi melakukan pemeriksaan IVA, sebagian besar (R2, R3) mengatakan di klinik dekat rumah dan lainnya (R1) mengatakan di rumah sakit. Mahasiswi yang telah melakukan 2 kali pemeriksaan IVA (R2, R3) kembali melakukannya di klinik kantor. Hasil dari pemeriksaan semua informan yang sudah IVA tersebut adalah normal. Selanjutnya, mahasiswi yang telah pemeriksaan IVA menambahkan bahwa agar terhindar dari kanker serviks, maka wanita harus menjaga kebersihan organ vital dan menjalankan gaya hidup sehat seperti 
tidak merokok, minum alcohol dan makan makanan yang sehat.

\section{Variabel Pengetahuan dalam Pemeriksaan IVA}

Informan

Pengetahuan

informan

mengenai ca-serviks sangat beragam. Berdasarkan hasil wawancara mendalam yang dilakukan, mahasiswi yang sudah IVA (R1, R2) mengetahui kanker serviks sebagai kanker leher rahim yang sangat berbahaya dan sangat mematikan atau mnejadi pembunuh nomor 1 atau 2 di dunia pada wanita. Pendapat berbeda (R3) menyebutkan bahwa ca-serviks merupakan kanker yang yang terjadi karena adanya hubungan seksual yang tidak sehat dan ini sejalan dengan sebagian besar informan yang belum IVA (R4, R6). Mahasiswi lainnya yang belum IVA (R4) menambahkan bahwa ca-serviks adalah kanker leher rahim yang terjadi pada wanita karena mereka jarang memeriksakan kesehatan dan karena genetik dan tambahan lainnya (R5) karena adanya jaringan baru yang tumbuh di rahim.

Informasi yang disampaikan masing-masing suami informan berbeda dengan istrinya, sebagian besar suami informan yang sudah IVA (R7, R8) hanya mengetahui jika kanker serviks adalah kanker di bagian intim/rahim perempuan dan hal ini sama dengan pendapat semua suami mahasiwi yang belum IVA (R10, R11, R12) sedangkan lainnya (R9) menganggap kanker serviks terjadi karena adanya radang akibat kekurangan cairan dan kejang-kejang. Berdasarkan ciri-cirinya, semua informan yang telah IVA menyatakan bahwa terdapat nyeri dibagian perut dan sebagian besar menambahkan jika terjadi perdarahan abnormal (haid yang lama dan perdarahan setelah berhubungan) dan keputihan abnormal. Hal ini sejalan dengan informasi yang diperoleh dari mahasiwi yang belum IVA (R4,R5,R6) bahwa ciri-ciri kanker serviks yakni keputihan abnormal, sebagian besar mengatakan (R4,R5) jika terjadi pendarahan ketika berhubungan seks kemudian masing-masing dari mereka yang belum IVA menambahkan jika berpendapatpenurunan berat badan (R4), sakit dibagian intim wanita ketika berhubungan (R5) dan perubahan siklus haid (R6).

Adapun suami masing-masing informan yang sudah dan belum IVA memiliki jawaban beragam, ada yang tidak tahu (R7, R10, R12), jika masih dini tidak ada gelala (R8) dan demam, bibir pecah-pecah, mata merah dan berbusa (R9) dan keputihan (R11). Penyebab terjadinya kanker serviks, semua mahasiswi yang sudah IVA dan sebagian besar yang belum IVA (R4, R6) menyatakan bahwa penyebabnya adalah karena adanya hubungan seksual yang tidak sehat (berganti-ganti pasangan), kemudian masing-masing menambahkan bahwa karena terserang virus yakni human pavilloma virus (R4, R5), wanita melahirkan di usia muda atau melahirkan 3 anak atau lebih (R1), karena wanita tidak menjaga kebersihan organ kewanitaannya (R2, R4) dan karena menjalankan gaya hidup tidak sehat (merokok dan obesitas) (R3). Adapun suami masingmasing informan, sebagian besar mengatakan tidak tahu dan sebagian kecil (R9) mengatakan jika kondisi badan lemah, kurang menjaga kesehatan, lingkungan kurang bersih dan kurang olahraga. Mengenai deteksi dini kanker serviks, baik mahasiswi yang sudah IVA maupun sebagian besar yang belum IVA (R1, R2, R3, R5, 
R6) mengatakan dengan pemeriksaan IVA dan papsmear dan sebagian besar yang belum IVA (R4, R5) juga menambahkan dengan pemberian imunisasi atau vaksin HPV.

Adapun suami masing-masing informan memiliki informasi yang berbeda dan beragam yakni sebagian besar (R7, R8, R12) mengatakan dengan melakukan pemeriksaan rutin ke dokter, menjaga kesehatan, kebersihan lingkungan, jangan berjemur dan terkena panas, banyak makan buahbuahan dan tidak berlemak serta berolahraga (R9), menjaga pola makan (R10) dan lainnya mengatakan tidak tahu (R11). Namun ada suami informan juga yang mengatakan dengan melakukan papsmear (R12). Mengenai informasi yang diperoleh tentang pemeriksaan IVA, semua mahasiswi menyatakah bahwa pemeriksaan IVA diperuntukkan bagi wanita yang sudah menikah dan aktif berhubungan seksual, pemeriksaan IVA dilakukan di fasilitas kesehatan seperti puskesmas, klinik dan rumah sakit. Selain itu, informasi lain yang diperoleh yakni bahwa pemeriksaan IVA dilakukan sebagai pemeriksaan awal untuk mencegah kanker serviks (R1, R3, R5) dan dilakukan minimal sekali setahun (R4).

Informasi ini hampir sama dengan informasi yang disampaikan oleh suami masing-masing mahasiswi yang sudah IVA seperti dilakukan dengan tujuan deteksi dini kanker rahim/vagina $(R 8, R 9)$ dan lainnya (R7) menambahkan bahwa dalam pemeriksaan IVA, dilakukan dengan mengambil jaringan serviks untuk diperiksa oleh tenaga kesehatan sedangkan semuasuami mahasiswi yang belum IVA tidak mengetahui sama sekali tentang pemeriksaan IVA.
Mengenai prosedur pemeriksaan IVA, mahasiswi (R1, R2, R3, R4) menyatakan bahwa prosedurnya hampir sama dengan pemasangan IUD yang mana pasien diperintahkan untuk tidur di meja ginekoid seperti posisi melahirkan lalu dimasukan alat cocor bebek untuk diperiksa vaginanya. Pendapat lain (R2, R3, R4, R6) bahwa pemeriksaan IVA dilakukan dengan mengambil cairan divagina lalu diperiksa di laboratorium dan hasilnya akan diberitahu 3 hari kemudian sedangkan lainnya (R5) punya pendapat lain bahwa pemeriksaan IVA itu dilakukan dengan cara menotolkan kapas yang telah diberi asamm asetat (cuka) ke mulut rahim.

\section{Variabel Sikap dalam Pemeriksaan IVA}

Untuk mengetahui sikap mahasiswi dalam pemeriksaan IVA, peneliti melakukan wawancara mendalam terhadap informan yang sudah melakukan pemeriksaan IVA serta mahasiswi yang belum melakukan pemeriksaan IVA. Hasil wawancara mendalam pada mahasiswi yang sudah IVA, sebagian besar berpendapat cepat, mudah, sebelum pelaksanaan dijelaskan tahaptahapnya, tidak nyeri. Sebagian kecil (R2) menyatakan nyeri saat pemeriksaan IVA di klinik kantor, dan R1 menyatakan hasilnya langsung bisa diketahui. Pertanyaan sikap pada mahasiswi yang belum IVA Sebagian besar (R4 dan R6) menyatakan risih/tidak nyaman karena harus dibuka-buka area kewanitaannya. Sebagian kecil (R5) berpendapat IVA sebagai screening awal, dan rasanya biasa saja. 


\section{Variabel Sarana Screening dalam Pemeriksaan IVA}

Untuk mengetahui sarana dalam pemeriksaan IVA, peneliti melakukan wawancara mendalam terhadap informan mahasiswi yang sudah melakukan pemeriksaan IVA, mahasiswi yang belum melakukan pemeriksaan IVA, suami mahasiswi yang sudah melakukan pemeriksaan IVA, suami mahasiswi yang belum melakukan pemeriksaan IVA dan bidan. Hasil wawancara mendalam tentang tempat yang dapat melakukan melakukan IVA, semua mahasiswi yang sudah melakukan IVA menjawab sebagian besar di fasilitas pelayanan kesehatan dekat rumah yaitu rumah sakit, klinik dan Puskesmas dan satu orang pernah melakukannya di klinik kantor. Suami mahasiswi yang sudah melakukan IVA sebagian besar menjawab mengetahuinya di fasilitas pelayanan kesehatan yaitu di rumah sakit dan klinik dan sebagian kecil ada yang menjawab mengetahuinya di tempat cek kesehatan dan kantor. Bidan klinik swasta (R13) menjawab di klinik swasta dan kantor RT atau RW jika diminta kader, dan bidan puskesmas (R14) menjawab di Puskesmas. Hasil wawancara tentang jarak tempat tinggal dengan tempat pemeriksaan IVA, semua mahasiswi baik yang sudah maupun yang belum melakukan IVA beserta suami, seluruhnya menjawab tersedia fasilitas kesehatan yang jaraknya dekat rumah. Untuk pertanyaan tentang petugas yang melakukan IVA, sebagian besar mahasiswi yang sudah dan belum melakukan IVA menjawab bidan, sedangkan sebagian kecil (R1) menjawab dokter. Sebagian besar mahasiwa yang belum melakukan IVA menjawab bidan, sedangkan sebagian kecil (R4) menjawab tidak tahu.
Untuk pertanyaan tentang biaya, sebagian besar mahasiswi yang sudah dan belum melakukan IVA menjawab gratis karena pakai BPJS, sedangkan sebagian kecil (R1) ada yang menjawab sebesar Rp.150.000, dan R2 yang menjawab sebesar Rp.50.000. Seluruh mahasiswi yang belum melakukan IVA menjawab gratis. Suami yang sudah melakukan IVA sebagian kecil ada yang menjawab tidak tahu, bayar seratus lima puluh ribu rupiah dan ada juga yang menjawab ditanggung BPJS. Sedangkan suami yang belum melakukan IVA, semuanya menjawab tidak tahu. Untuk bidan R14 menjawab gratis karena pakai BPJS dan bidan R13 ada yang gratis jika peserta BPJS serta bayar kalau umum. Pertanyaan tentang saran terhadap sarana IVA, sebagian besar mahasiwa yang sudah melakukan IVA mengharapkan informasi jadwal pelaksanaan IVA rutin dan tempat pemeriksaan IVA sudah bagus. Ada juga yang sebagian kecil (R3) mengeluh tempat tunggu antri, agak panas tapi ruang periksa nyaman karena sudah ber AC. Sebagian besar mahasiwa yang belum melakukan IVA (R4 dan R5) mengharapkan petugas memberi info yang lebih jelas ke masyarakat seperti demo IVA dan R6 menyarankan agar pemeriksaan IVA dijadwalin.

\section{Variabel Paparan Informasi IVA}

Untuk mengetahui sejauh mana paparan informasi yang diperoleh tentang pemeriksaan IVA, peneliti melakukan wawancara mendalam kepada para informan, yang terdiri dari: mahasiswi yang sudah melakukan IVA dan yang belum melakukan IVA besertanya suami dari setiap informan tersebut. Adapun petanyaannya terdiri dari: Apakah sudah pernah mendapat 
informasi tentang IVA, dari mana sumber informasi diperoleh, kapan waktunya, bagaimana isi informasi yang didapat dan saran untuk penyebar luasan informasi. Hasil dari wawancara mendalam pada informan yang sudah melaksanakan IVA diperoleh bahwa semua informan sudah pernah mendapatkan informasi pemeriksaan IVA, yang berisi tentang pengertian, tujuan, waktu pelaksanaan pemeriksaan IVA dan tanda gejala kanker rahim. Sebagian besar informan mengatakan bahwa sumber informasi tersebut diperoleh dari media elektronik dan internet, sebagian kecil lainnya R1 menyatakan dapat dari surat edaran tentang pelayanan IVA gratis dan R2 dapat dari buku pelatihan tentang IVA.

Adapun waktu menerima informasi tersebut, sebagian besar informan menyatakan mendapat informasi tentang pentingnya pemeriksaan IVA sudah lebih dari 3 kali pada tahun 2015 sebelum mengikuti pemeriksaan IVA dan sebagian kecil informan (R2) mengatakan saat mengikuti Pelatihan IVA pada tahun 2014. Sedangkan bagi informan yang belum pernah melakukan pemeriksaan IVA mengatakan bahwa semuanya pernah mendengar tentang pengertian, manfaat tentang pemeriksaan IVA, tanda dan gejala kanker serviks. Sebagian besar mengatakan bahwa informasi tersebut diperoleh dari media social dan selebaran/leaflet tentang IVA dan sebagian kecil lainnya (R6) mengatakan bahwa informasi berasal dari Puskesmas. Adapun waktu informasi tersebut diperoleh semua informan mengatakan sudah lama, sekitar 1-2 tahun yang lalu, antara tahun 2017-2018 dan sebagian kecil (R6) mengatakan saat berkunjung ke Puskesmas tahun 2018. Hasil wawancara mendalam kepada suami dengan istri yang sudah dan belum melakukan IVA diperoleh bahwa sebagian besar informan (R7, R9, R10, dan R11) mengatakan belum pernah mendengar informasi secara spesifik tentang pengertian, manfaat dan waktu pelaksanaan pemeriksaan IVA, R8 mengatakan pernah mendengar informasi tersebut dari media elektronik sekitar tahun 2018, sedangkan R12 mengatakan pernah mendengar sekilas tentang pengertian, manfaat dan waktu pelaksanaan pemeriksaan IVA dari istrinya sendiri, sekitar tahun 2015.

Pada pertanyaan saran informasi untuk pemeriksaan IVA, peneliti hanya menanyakan kepada informan wanita yang sudah melakukan IVA dan yang belum melakukan IVA. Hasil wawancara mendalam kepada informan yang sudah melakukan IVA diperoleh bahwa sebagian besar mengatakan penyebaran informasi dapat dilakukan dengan pemasangan poster/spanduk tentang pemeriksaan IVA dan pencegahan kanker serviks, R3 menyarankan melalui penyuluhan langsung ke masyarakat, dan R1 menyarankan dengan dibuatkan surat edaran tentang pelayanan pemeriksaan IVA bagi seluruh pegawai wanita di klinik kantor. Sedangkan hasil dari informan yang belum pernah melakukan pemeriksaan IVA, diperoleh bahwa sebagian besar mengatakan penyebaran informasi dapat dilakukan secara langsung pada kelompok tertentu dan masyarakat luas, dan sebagain kecil lainnya (R6) memberikan saran agar informasi tentang pemeriksaan IVA dapat dilakukan melalui media social. 
VariabelDukungan Tenaga Kesehatan

Untuk mengetahui dukungan tenaga kesehatan dalam pemeriksaan IVA, peneliti melakukan wawancara mendalam terhadap informan yang sudah melakukan pemeriksaan IVA, mahasiswi yang belum melakukan pemeriksaan IVA, suami mahasiswi yang sudah melakukan pemeriksaan IVA dan suami mahasiswi yang belum melakukan pemeriksaan, serta bidan selaku tenaga kesehatan. Hasil wawancara mendalam pada mahasiswi yang sudah IVA, sebagian besar (R1 dan R2) berpendapat tidak ada penyuluhan mengenai pemeriksaan IVA yang dilakukan oleh tenaga kesehatan. Sebagian kecil (R3) menyatakan dilakukan penyuluhan oleh tenaga kesehatan namun belum luas sasarannya. Sedangkan hasil wawancara dengan mahasiswi yang belum melakukan pemeriksaan IVA, R4 dan R6 berpendapat belum pernah adanya penyuluhan atau tidak disarankan oleh tenaga kesehatan untuk melakukan pemeriksaan IVA. Sebagian kecil (R5) menyatakan tenaga kesehatan pernah mendatangi ke sekitar rumah untuk penyuluhan mengenai pemeriksaan IVA.

Hasil wawancara mendalam dengan suami mahasiswi yang sudah melakukan pemeriksaan IVA mengenai dukungan tenaga kesehatan, R7 mengatakan hanya melihat di spanduk, R8 mengatakan kurang adanya sosialisasi dari tenaga kesehatan, dan R9 mengatakan ada penyuluhan dari tenaga kesehatan di kelurahan mengenai pemeriksaan IVA. Sedangkan dari hasil wawancara kepada suami mahasiswi yang belum melakukan IVA, semuanya mengatakan tidak tahu mengenai dukungan tenaga kesehatan tehadap pemeriksaan IVA. Dari hasil wawancara kepada Bidan sebagai petugas kesehatan yang melakukan pemeriksaan IVA, bidan swasta (R13) menyatakan bahwa penyuluhan pemeriksaan IVA jarang dilakukan, kecuali kerjasama dan jika dimintakader baru akan dilakukan pemeriksaan. Sedangkan bidan puskesmas (R14) menyatakan dukungan tenaga kesehatan mengenai pemeriksaan IVA dilakukan dengan konseling individu (untuk yang punya keluhan), dan melakukan penyuluhan ke masyarakat mengenai pemeriksaan IVA dengan dana BOK.

Hasil wawancara mendalam pada mahasiswi yang sudah IVA saran yang diberikan terhadap dukungan tenaga kesehatan, sebagian besar berpendapat diperlukannya sosialisasi dan penyuluhan ke semua wilayah. Sebagian kecil menyatakan agar lebih banyak dilakukan penyebaran informasi. Sedangkan hasil wawancara mendalam pada mahasiswi yang belum melakukan IVA saran yang diberikan kepada tenaga kesehatan agar masyarakat mau melakukan pemeriksaan IVA, R4 menyatakan tenaga kesehatan senantiasa menyarankan jika ketemu ibu yang sedang hamil atau melahirkan agar dapat melakukan pemeriksaan IVA, R5menyatakan bahwa semua tenaga kesehatan harus berkompeten dalam melakukan pemeriksaan IVA sehingga semakin banyak yang bisa melakukan pemeriksaan IVA, dan R6 menyatakan agar tenaga kesehatan dapat menyediakan info yang lebih mudah diakses masyarakat mengenai pemeriksaan IVA. Hasil wawancara yang dilakukan kepada bidan sebagai tenaga kesehatan apabila Wanita Usia Subur (WUS) atau suaminya jika 
menolak melakukan pemeriksaan IVA juga ketika pasangan WUS berisiko menolak pemeriksaan IVA, bidan (R13) menyatakan akan memberikan inform consent sebagai bukti bahwa pasien menolak untuk dilakukan pemeriksaan IVA dan Bidan (R14) menyatakan tetap tetap menganjurkan degan menjelaskan risikonya dan akan memberikan rujukan ke dokter untuk IVA atau papsmear.

\section{VariabelDukungan Suami}

Untuk mengetahui dukungan suami dalam pemeriksaan IVA, peneliti melakukan wawancara mendalam terhadap informan yang sudah melakukan pemeriksaan IVA, mahasiswi yangbelum melakukan pemeriksaan IVA, suami mahasiswi yang sudah melakukan pemeriksaan IVA dan suami mahasiswi yang belum melakukan pemeriksaan IVA. Hasil wawancara mendalam semua informan berpendapat sebagai wujud dukungan suami mengenai pemeriksaan IVA walaupun suami kurang tahu tentang IVA tapi mendukung istri dengan mengijinkan dan tidak melarang untuk melakukan pemeriksaan IVA. Sebagian kecil, yakni R4 menyatakan suaminya cuek saja jika ingin melakukan pemeriksaan IVA, sedangkan informan R5 menyatakan wujud dukungan suami memberikan motivasi untuk melakukan pemeriksaan IVA jika diperlukan.

Hasil wawancara dengan suami mahasiswi yang telah melakukan pemeriksaan IVA dan suami dari mahasiswi yang belum IVA, semuanya menyatakan mengizinkan istrinya untuk melakukan pemeriksaan IVA. Bahkan semua suami dari mahasisiwi yang belum IVA (R10, R11, dan R12) menyatakan akan mengijinkan, mengantar dan membiayai jika istri akan pemeriksaan IVA. Hasil wawancara dengan suami mahasiswi yang sudah dan belum melakukan pemeriksaan IVA, yang dilakukan oleh suami agar istri memahami pentingnya IVA sebagian besar menyatakan istri lebih paham dan lebih tau mengenai pemeriksaan IVA. Sebagian kecil (R8) menyatakan akan meminta istri baca di internet mengenai pemeriksaan IVA.

\section{PEMBAHASAN}

\section{Variabel Perilaku}

Tiga orang mahasiswi yang melakukan pemeriksaan IVA bertujuan mengetahui deteksi dini kanker serviks. Hal ini sesuai dengan penelitian sebelumnya proporsi terbesar tentang alasan mengapa ibu pernah melakukan pemeriksaan test IVA adalah karena ingin tahu bagaimana kondisi kesehatannya terutama kesehatan rahimnya, yaitu sebanyak 46 responden (56,5\%) (Melva, 2014). Perilaku mahasiswi yang melakukan pemeriksaan IVA juga karena adanya kebijakan kantor untuk melakukan pemeriksaan IVA bagi karyawan wanita. Menurut Notoatmodjo (2012) paksaan dalam bentuk upaya tidak langsung seperti undang-undang atau peraturan-peraturan (law enforcement), instruksi-instruksi dan secara langsung melalui tekanan-tekanan (fisik atau nonfisik), sanksi dan sebagainya.

Masih menurut Notoatmodjo (2012) pendidikan atau promosi kesehatan adalah suatu bentuk bentuk intervensi atau upaya yang ditujukan kepada perilaku, agar perilaku tersebut kondusif. Sebagian besar suami mahasiswi mengetahui tujuan pemeriksaan IVA dan mendukung isterinya melakukan pemeriksaan IVA, sedangkan sebagian kecil tidak 
mengetahui. Sebagian besar mahasiswi yang belum karena telah melakukan pemeriksaan papsmear. Menurut Green (1980) perilaku kesehatan dipengaruhi olehpengetahuan, persepsi, sikap, keinginan, kehendak, motivasi dan niat.Sedangkan sebagian kecil karena takut diperiksa IVA. Hal ini sesuai dengan penelitian sebelumnya, respondenyang bekerja tidak termotivasi melakukan pemeriksaan Inspeksi Viasul Asam asetat (IVA), takut/malu akan diagnosa yang dikemukakan dokter serta beberapa dari responden tidak mengutamakan kesehatan melainkan lebih memperhatikan melakukan kesibukan pekerjaan rumah tangga setelah kembali dari kantor (Pakkan, 2017).

Penelitian

menunjukkan bahwa terdahulu pemeriksaan IVA dipengaruhi tingkat pendidikan menunjukkan hasil yang signifikasi lebih kecil dari 0,05 $(0,00<0,05)$, diikuti oleh pengaruh ekonomi menunjukkan hasil yang signifikasi lebih kecil dari 0,05 $(0,00<0,05)$, pengaruh usia menunjukkan hasil yang signifikasi lebih kecil dari $0,05 \quad(0,03<0,05)$, pengaruh pendidikan kesehatan menunjukkan hasil yang signifikasi lebih kecil dari $0,05 \quad(0,00<0,05)$, pengaruh lingkungan menunjukkan nilai signifikasi lebih kecil dari 0,05 $(0,00<0,05)$, dan yang terakhir kepercayaan menunjukkan nilai yang signifikasi lebih kecil dari 0,05 $(0,00<0,05)$. Kesimpulan ada hubungan faktor-faktor minat pemeriksaan IVA dengan minat pemeriksaan IVA di Puskesmas Tretep Kabupaten Temanggung (Lestari, 2017).

\section{Variabel Pengetahuan}

Pengetahuan adalah merupakan hasil dari tahu dan ini terjadi setelah orang melakukan pengindraan terhadap objek tertentu. Tingkat pengetahuan dimulai dari tahu, paham, aplikasi, analisis, sintesis dan evaluasi mempengaruhi perilaku kesehatan. Seluruh mahasiswi baik yang belum maupun yang memiliki pengetahuan yang baik tentang kanker serviks. Sebagian besar suami sudah mengetahui kanker serviks, sedangkan sebagian kecil tidak tahu tentang kanker serviks. Perilaku kesehatan selain dipengaruhi pengetahuan, tetapi juga dipengaruhi kepercayaan, tradisi dan sistem nilai masyarakat juga mendorong atau menghambat periksa IVA (Notoatmodjo, 2012).

\section{Variabel Sikap}

Sikap merupakan reaksi atau respon yang masih tertutup terhadap suatu stimulus atau objek. Sikap juga memiliki tingkatan mulai dari menerima, merespon, menghargai dan bertanggungjawab untuk kesehatan dirinya sendiri. Seluruh mahasiswi mendukung pemeriksaan IVA untuk deteksi dini kanker serviks. Sebagian besar suami mendukung isterinya untuk melakukan pemeriksaan IVA karena telah mengetahui tujuan pemeriksaan IVA. Menurut Lewin dalam Notoatmodjo (2012) individu bertindak melawan atau mengobati penyakit karena kerentanan yang dirasakan terhadap suatu penyakit, keseriusan yang dirasakan, manfaat yang diterima dari rintangan yang dialami yang dialami dalam tindakannya melawan penyakit dan hal-hal yang memotivasi tindakan tersebut. 
Berdasarkan penelitian terdahulu yang dilakukan di Puskesmas Pekauman Banjarmasin tentang hubungan sikap dan lingkungan sosial wanita usia subur (WUS) dengan pemeriksaan IVA di Puskesmas Pekauman Banjarmasin didapatkan hasil bahwa tidak ada hubungan antara sikap WUS dengan pemeriksaan IVA, berdasarkan hasil tanya jawab yang dilakukan telah didapatkan bahwa sebagian besar sikapyang dimiliki responden positif namun berbanding terbalik dengan perilaku yang dimilikinya (Rahmayani, 2018). Penelitian terdahulu responden yang belum berpartisipasi dalam pemeriksaan IVA lebih banyak ditemukan pada kelompok responden dengan peresepsi kerentanan rendah (97,1\%) dibandingkan kelompok dengan persepsi kerentanan tinggi (86,5\%) (Titisari, 2018).

\section{Variabel Sarana Screening}

Seluruh mahasiswi menjawab sarana screening sangat dekat dengan rumah. Menurut Green dalam Notoatmodjo (2012), faktor pemungkin (enabling factors) mencakup ketersediaan sarana dan prasarana atau fasilitas kesehatan bagi kesehatan mempengaruhi masyarakat untuk mencari pengobatan. Hal ini berhubungan dengan penelitian sebelumnya faktor yang berhubungan dengan kunjungan pemeriksaan IVA yaitu usia, pekerjaan, paritas, jaminan kesehatan, akses terhadap layanan kesehatan, dan pengetahuan (Pratiwi, 2015).

\section{Variabel Paparan Informasi}

Seluruh mahasiswi sudah mendapatkan informasi melalui media elektronik dan cetak. Sebagian besar sudah mengetahui pentingnya pemeriksaan, namun ada juga yang belum mengetahui. Menurut teori Snehandu B. Kar, Kar menganalisa perilaku kesehatan dengan bertitik tolak bahwa perilaku itu merupakan fungsi dari niat, dukungan sosial, ada atau tidaknya informasi tentang kesehatan atau fasilitas kesehatan, otonomi daerah dan situasi. Menurut penelitian sebelumnya faktor paparan informasi berhubungan signifikan dengan perilaku pemeriksaan IVA. Selain itu, faktor dukungan petugas kesehatan juga berhubungan signifikan dengan perilaku pemeriksaan IVA. Sedangkan dari hasil analisa uji regresi logistik menunjukkan bahwa faktor paparan informasi merupakan faktor yang lebih dominan berhubungan dengan perilaku pemeriksaan IVA setelah dikontrol faktor dukungan petugas kesehatan (Dewi, 2014).

\section{Variabel Dukungan Tenaga Kesehatan}

Dalam penelitian semua bidan mendukung adanya pemeriksaan IVA. Menurut Green (1980) faktor penguat (reinforcing) meliputi faktor sikap dan perilaku tokoh masyarakat(toma), tokoh agama (toga), sikap dan perilaku tenaga kesehatan. Menurut penelitian terdahulu bahwa komunikasi, karakteristik dukungan puskesmas dan sikap penanggungjawab berpengaruh secara langsung (Anggraini, 2015).

\section{Variabel Dukungan Suami}

Semua sumi mendukung isteri apabila pemeriksaan IVA demi kesehatan.Menurut teori Green (1980) faktor penguat (reinforcing) meliputi faktor sikap dan perilaku tokoh masyarakat (toma), tokoh agama (toga), sikap dan perilaku tenaga kesehatan. Menurut penelitian sebelumnya diketahui bahwa dari 30 orang 
responden yang mendapat dukungan suami yaitu 23 orang $(76,7 \%)$ melakukan tindakan pemeriksaan IVA dan dari 64 responden yang tidak mendapat dukungan suami semuanya tidak melakukan tindakan pemeriksaan IVA. Hal ini menunjukkan bahwa terdapat hubungan yang signifikan antara dukungan suami dengan tindakan pemeriksaan IVA (Meliasari,2014). Menurut penelitian sebelumnya terdapat hubungan yang signifikan antara dukungan keluarga dengan minat WUS (Wanita Usia Subur) dalam melakukan pemeriksaan IVA (Inspeksi Visual dengan pulasan Asam Asetat) di Desa Pangebatan Kabupaten Banyumas (Rahma, 2012)). Penelitian lain juga menyatakan ada hubungan yang signifikan antara umur, pendidikan, status perkawinan, pengetahuan, sikap, informasi paparan, dukungan suami, dan dukungan petugas kesehatan untuk WUS melakukan tes IVA. Faktor yang paling dominan dukungan suami (Sihombing, 2016).

\section{SIMPULAN DAN SARAN}

\section{Simpulan}

Perilaku pemeriksaan IVA mahasiswi Magister FKM UI Angkatan 2018 sudah bagus karena sudah banyak yang melakukan pemeriksaan IVA dan yang belum pemeriksaan IVA dikarenakan telah melakukan pemeriksaan papsmear meskipun ada juga yang masih malu dan takut melakukan pemeriksaan tersebut. Pengetahuan mahasiswi Magister FKM UI Angkatan 2018 tentang pemeriksaan IVA sudah cukup bagus karena telah mampu menjelaskan dengan baik dan beragam mengenai kanker serviks, ciriciri, penyebab, deteksi dini, pemeriksaan IVA dan prosedurnya.
Mahasiswi Magister FKM UI Angkatan 2018 telah memiliki sikap positif terhadap pemeriksaan IVA meskipun masih ada yang merasa takut dan risih dengan pemeriksaan tersebut. Keterpaparan informasi mahasiswi Magister FKM UI Angkatan 2018 tentang pemeriksaan IVA sudah cukup bagus khususnya yang bersumber dari media sosial. Dukungan tenaga kesehatan dalam pemeriksaan IVA menurut mahasiswi Magister FKM UI Angkatan 2018 belum maksimal dilakukan. Fasilitas pemeriksaan IVA bagi mahasiswi Magister FKM UI Angkatan 2018 mudah karena tersedia di fasilitas kesehatan terdekat di daerah masing-masing dengan biaya gratis bagi pengguna BPJS.

\section{Saran}

Diharapkan kepada seluruh fasilitas kesehatan untuk lebih mengoptimalkan sosialisasi baik berupa penyuluhan massal di fasilitas kesehatan dan acara kemasyarakatan, ataupun penyuluhan perorangan saat wanita kontrol rutin di fasilitas kesehatan atau melalui kunjungan rumah agar minat wanita untuk melakukan pemeriksaan IVA semakin tinggi dan dapat mencover secara keseluruhan. Diharapkan pula Himpunan Mahasiswa Pascasarjana FKM UI, khususnya Seksi Pengabdian Masyarakat mengadakan pemeriksaan IVA gratis di lingkungan FKM UI.

\section{KEPUSTAKAAN}

Anggraini FD 2015. Faktor Yang Mempengaruhi Implementasi Program Deteksi Dini Kanker Serviks Melalui Pemeriksaan Iva (Inspeksi Visual Asam Asetat) Di Puskesmas Wilayah Kota Surabaya. Journal of Health Sciences, 8(1). 
Christin AF 2016. Faktor-Faktor Yang Berhubungan Dengan Deteksi Dini Kanker Leher Rahim Di Kecamatan Gisting Kabupaten Tanggamus Lampung. Fakultas Kesehatan Masyarakat, Universitas Malahayati Bandar Lampung, Jurnal Kesehatan, Volume Vii, Nomor 2, Agustus 2016, Hlm 228-237.

Dewi L 2014. Faktor-Faktor Yang Berhubungan Dengan Perilaku Wanita Usia Subur Dalam Deteksi Dini Kanker Serviks Dengan Metode Pemeriksaan Inspeksi Visual Asam Asetat (IVA) Di Wilayah Kerja Puskesmas Tanjung Hulu Pontianak Timur Tahun 2014. Jurnal ProNers, 1(1).

Darwati L, MuhithA, \& Nurwijayanti N 2017. Analisis Of Educational Factors, Interest and Motivation Towards the Behavior of Early Detection of Ca Cerviks in Women of Fertilite Age In the upthealth Center Kembangbahu Lamongan. Publikasi hasil penelitian, $0(0)$, 135-158. Retrieved from http:/ / ejurnalp2m.stikesmajapahitmoj okerto.ac.id/index.php/publikasi_stik es_majapahit/article/view/279/252.

Ferlay J, Soerjomataram I, Dikshit R, Eser S, Mathers C, Rebelo M,Bray F 2015. Cancer incidence and mortality worldwide: Sources, methods and major patterns in GLOBOCAN 2012. International Journal of Cancer, 136(5), E359-E386.

https:// doi.org/10.1002/ijc.29210

Green LW and Kreuter MW 2005. Health Program Planning: An Educational and Ecological Approach. 4th edition. NY: McGraw-Hill Higher Education, 2005.

GP Mayun Mayura dr I 2012. Sensitifitas dan Spesifisitas Inspeksi Visual Asam Asetat Pada Lesi Serviks DI Desa Nyambu Kediri Tabanan.

Kemenkes RI 2015. Panduan Program Nasional Gerakan Pencegahan dan Deteksi Dini Kanker Leher Rahim dan Kanker Payudara. Retrieved April 1, 2018, from http://www.pptm.depkes.go.id/cms/
frontend/ebook/Buku_Panduan_Pela ksanaan_iva-sadanis_2015.pdf

Kurniawati Indah 2015. Pengaruh Pengetahuan, Motivasi Dan Dukungan Suami Terhadap Perilaku Pemeriksaan Iva Pada Kelompok Wanita Usia Subur Di Puskesmas Kedungrejo. Masters thesis Program Magister Kedokteran Keluarga, Universitas Sebelas Maret.

Lestari RP, \& Sarwinanti S 2017. ANALISIS FAKTOR FAKTOR YANG MEMPENGARUHI MINAT PEMERIKSAAN IVA DI PUSKESMAS TRETEP KABUPATEN

TEMANGGUNG (Doctoral

dissertation, Universitas' Aisyiyah Yogyakarta).

Martha Evi, Kresno Sudarti 2016. Metodologi Penelitian Kualitatif Untuk Bidang Kesehatan. 1nd ed. Jakarta: Rajawali Pers ; 2016.

Meliasari D 2015. PENGETAHUAN DAN DUKUNGAN SUAMI BERHUBUNGAN DENGAN TINDAKAN PEMERIKSAAN IVA PADA PASANGAN USIA SUBUR (PUS) DI DESA SUNGGAL KANAN TAHUN 2014. Jurnal Ilmiah PANNMED (Pharmacist, Analyst, Nurse, Nutrition, Midwivery, Environment, Dentist), 9(3), 226-230.

Melva M, Hasibuan Y, \& Meliasari D 2014. Pengaruh Pengetahuan Dan Sikap Tentang Kanker Serviks Terhadap Pemeriksaan Iva Pada Wanita Usia Subur Di Desa Tuntungan Ii Kecamatan Pancur Batu Tahun 2013. Jurnal Ilmiah PANNMED (Pharmacist, Analyst, Nurse, Nutrition, Midwivery, Environment, Dentist), 8(3), 238-243.

Ummiyati M, Widati S, \& Hargono R 2017. The Effect of Family Income, Knowledge and Cultural Value on Early Detection Behavior of Cervical Cancer. Dama International Journal of Researchers Available@@ Www.damaacademia.com Dama International Journal of Researchers, 18(7), 2343-6743. Retrieved from 
http://www.damaacademia.com/issu e/volume2/issue7/DIJR-JL-007.pdf

Pertiwi NDE, \& INDRIANI I 2015. Faktorfaktor yang berhubungan dengan kunjungan pemeriksaan IVA/pap smear pada ibu-ibu PKK di Dusun Tajem Depok Sleman (Doctoral dissertation, STIKES'Aisyiyah Yogyakarta).

Rahma RA, \& Prabandari F 2012. Beberapa faktor yang mempengaruhi minat wus (wanita usia subur) dalam melakukan pemeriksaan IVA (inspeksi visual dengan pulasan asam asetat) di Desa Pangebatan Kecamatan Karanglewas Kabupaten Banyumas tahun 2011. Bidan Prada: Jurnal Publikasi Kebidanan Akbid YLPP Purwokerto, 3(01).

Pakkan R 2017. Faktor-faktor Yang Berhubungan Dengan Motivasi Ibu Melakukan Pemeriksaan Metode Inspeksi Visual Asam Asetat (Iva). Jurnal Ilmiah Bidan, 2(1), 12-17.

Rahmayani D, \& Utami LKD 2018. Hubungan Sikap Dan Lingkungan Sosial WUS Dengan Pemeriksaan IVA Di PUSKESMAS Pekauman Banjarmasin. Dinamika Kesehatan Jurnal Kebidanan dan Keperawatan, 9(1), 215224.Sihombing, M., \& Windiyaningsih, C. (2016). Faktor Penentu Pemeriksaan
IVA Pada Wanita Usia Subur di Puskesmas Pademangan, Suku Dinas Kesehatan Jakarta Utara 2015. Jurnal Bidang Ilmu Kesehatan, 6(1), 9.

Sutopo HB 2002. Metode Penelitian Kualitatif. Bandung : PT. Remaja Rosda Karya.

Titisari IA, Riyanti E, \& Prabamurti PN 2018. Aplikasi Teori Health Belief Model pada Partisipasi Wanita Usia Subur (WUS) Dalam Pemeriksaan IVA di Kelurahan Kalibanteng Kulon. Jurnal Kesehatan Masyarakat (eJournal), 6(5), 751-759.

Williams-Brennan L, Gastaldo D, Cole DC, \& Paszat L 2012. Social determinants of health associated with cervical cancer screening among women living in developing countries: A scoping review. Archives of Gynecology and Obstetrics, 286(6), 1487-1505. https://doi.org/10.1007/s00404-0122575-0

Yuliwati 2012. Faktor-faktor yang berhubungan dengan perilaku wus dalam deteksi dini kanker leher rahim metode iva di wilayah puskesmas prembun kabupaten kebumen tahun 2012. 